\title{
OXYGEN FUGACITY OF GASES AND ROCKS FROM MOMOTOMBO VOLCANO, NICARAGUA: APPLICATION TO VOLCANOLOGICAL MONITORING
}

\author{
G. BENHAMOU, ${ }^{1}$ P. ALLARD, ${ }^{1}$ J.C. SABROUX, ${ }^{1}$ G. VITTER, ${ }^{2}$ \\ D. DAJLEVIC, ${ }^{3}$ and A. CREUSOT ${ }^{4}$
}

\begin{abstract}
The oxygen fugacity $\left(f_{\mathrm{O}_{2}}\right)$ and the $\mathrm{f}_{\mathrm{O}_{2}}$ versus $\mathrm{T}^{\circ} \mathrm{C}$ relationship of high-temperature $\left(600^{\circ}-860^{\circ} \mathrm{C}\right)$ gas emissions from Momotombo volcano, Nicaragua, was determined from both field electrochemical measurements (electrolytic cell as- sembly) and thermodynamic computations on gas samples collected between 1978 and 1985. It was then compared with the intrinsic $\mathrm{f}_{\mathrm{O}_{2}}$ of fresh and altered lavas from the last eruption (1905), as measured between $500^{\circ}$ and $1100^{\circ} \mathrm{C}$ in laboratory. The electrochemical results show that the oxygen fugacity of Momotombo fumaroles, at equivalent temperature, is much higher than that of the fresh 1905 lava (FMQ buffer) and closer to that of their altered wall rocks ( NNO buffer). The equilibrium $\mathrm{O}_{2}$ fugacities calculated from the chemistry of gas samples confirm this pattern. However, they suggest that the gas mixtures preserve the (variable) memory of a higher thermal equilibrium achieved at depth, under temperature and $\mathrm{f}_{\mathrm{O}_{2}}$ conditions of up to $1050^{\circ} \mathrm{C}$ and $10^{-9.0} \mathrm{~atm}$, respectively, which correspond to the cross over between the $\mathrm{f}_{\mathrm{O}_{2}}-\mathrm{T}$ gas and lava trends. These data thus support the idea that Momotombo volcanic gases, released in a period of increasing activity, escape from a shallow magma body before suffering a variable oxidation during their ascent through both unbuffered cooling and reactions with environmental fluids and rocks. This late oxidation is weaker at central fumaroles than at peripherical ones. While between 1978 and 1985 the temperature of the hottest fumarole increased from $750^{\circ}$ to $865^{\circ}-900^{\circ} \mathrm{C}$, the equilibrium $f_{2}$ of the gas decreased by nearly one order of magnitude (at comparable equilibrium temperature). Such an evolution presumably reflects an increasing connection between the surface exhalations and the magma degassing at depth along with time. This work underlines the possibility of monitoring the processes of magma ascent and gas-magma separation within a volcano before an eruption by continuously recording the changes of both oxygen fugacity and temperature in hot fumaroles.
\end{abstract}

\section{Introduction}

Changes in the physics and chemistry of volcanic gas emanations may provide useful warning of forthcoming eruptions. This working hypothesis, which constitutes the basis of any program of volcanic gas monitoring, is founded on both theoretical background on the behavior of magmatic

\footnotetext{
${ }^{1}$ Centre des Faibles Radioactivités, CNRS, Gif sur Yvętte, France.

${ }_{2}$ Laboratoire d'Energétique électrochimique, ENSEEG, Domaine universitaire, Saint Martin d'Hères, France.

${ }^{3}$ Commissariat à l'Energie Atomique, SPIN /DPT, Gif sur Yvette, France.

${ }^{4}$ Instituto Nicaraguense de Energia, Managua, Nicaragua.
}

Copyright 1988 by the American Geophysical Union.

Paper number 7B7015.

0148-0227/88/007B-7015\$05.00 volatiles and experimental observations on volcanoes [see Anderson, 1975; Gerlach and Nordlie, 1975; Tazieff and Sabroux, 1983].

The temperature and the oxidation state of volcanic gases, the latter being strongly and positively dependent on the former one, are among the parameters which can be expected to vary prior to an eruption. Increases of fumarole or crater lake temperatures, clearly due to an increasing thermal output, were indeed recorded before many eruptions, even though such changes do not ascertain by themselves that an eruptive outbreak will follow. In contrast, preeruptive variations of the oxidation state or, more specifically, of the oxygen fugacity $\left(\mathrm{f}_{02}\right)$ of volcanic gases were not yet clearly evidenced. The only observations suggestive of such a change concern an increase in the reducing capacity (roughly say the $\mathrm{H}_{2}$ partial pressure) of volcanic exhalations before some seismic or volcanic events [Sato et al., 1976; Sato and McGee, 1981; Carapezza et al., 1985].

The oxygen fugacity of volcanic gases equilibrated at $1000^{\circ}-1200^{\circ} \mathrm{C}$ with erupting lavas usually ranges between $10^{-10}$ and $10^{-7}$ atm [Heald et al., 1963; Sato and Moore, 1973; Allard et al., 1977; Gerlach, 1983], which is typical of the oxidation state of most basaltic and andesitic rocks at these temperatures [Fudali, 1965; Sato and Moore, 1973; Ulmer et al., 1976; Haggerty, 1978]. As this parameter is much less dependent on pressure than temperature, the gases which escape from such magmas at shallow to moderate depth within a volcano should initially have quite similar $f_{02}$. However, during their migration toward the surface, after separation from the melts, these fluids will become exposed to oxidation: first, their cooling in closed system would already keep their $\mathrm{O}_{2}$ content at a higher level than in redox conditions buffered by the silicate at equivalent temperature [Gerlach and Nordlie, 1975; Gerlach, 1983]; second, by encountering and being able to react with a much more oxidized environment, with $\mathrm{f}_{\mathrm{O} 2}$ rising up to $0.21 \mathrm{~atm}$ at the surface, they will become submitted to a strong oxidizing influence; third and last, their $\mathrm{O}_{2}$ fugacity might be increased by the faster migration of light reduced species such as $\mathrm{H}_{2}$ [Sato and Wright, 1966; Sato, 1978]. Hence volcanic gases enroute to the surface can only undergo oxidation with respect to their initial state. The greater the depth of gas-magma separation, the larger the potential extent of this effect. On the contrary, if that separation occurs at a decreasing depth, that is, if the magma approaches the surface, this oxidizing influence will become progressively smaller and the gases should then preserve a more reduced signature. Basically, therefore, we may expect that during magma ascent and, particularly, before eruption the $\mathrm{O}_{2}$ fugacity of gas emanations from quiescent volcanoes will tend to decrease at a given temperature or, better, will evolve along more reduced $\mathrm{f}_{\mathrm{O} 2}$-T trends, toward $\mathrm{f}_{\mathrm{O} 2}$ and $\mathrm{T}$ conditions typical of the corresponding melt.

We have applied such a tentative approach of volcano monitoring to Momotombo volcano, Nicaragua, which has shown evidence of increasing activity since 1973 . The oxygen fugacity of high-temperature fumarolic gases released by this volcano in 1978-1985 was determined from both in situ electrochemical measurements and thermodynamic computations on collected gas samples and was then compared with the oxygen fugacity of the lava from the last eruption, as measured in the laboratory. 


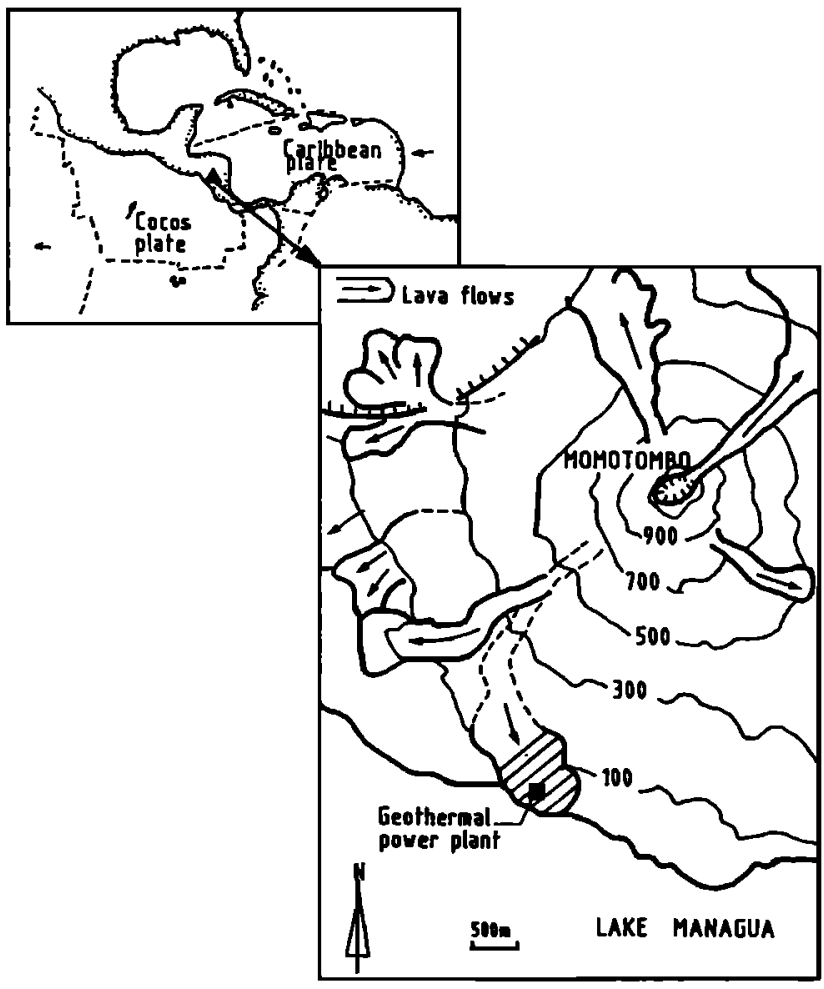

Fig.1. Geographical position and general topo- graphy of Momotombo volcano.

Sato and Moore [1973] were the first ones to carry out fo2 electrochemical measurements on volcanic gases and rocks from a same volcano, taking the opportunity of an eruption of Mount Etna, Sicily. The work presented here constitutes an extension of their study, with the complementary use of $\mathrm{f}_{2}$ information given by the chemistry of gas samples. It applies specifically to volcanoes in preeruptive stage and to the forecast of their possible magmatic outbreak.

\section{Momotombo Volcano}

Momotombo, $1190 \mathrm{~m}$ above sea level (Figure 1), is the southernmost active volcano of the Marrabios chain, northern Nicaragua, which constitutes a section of the Central American volcanic belt. Its generation is thus related to the subduction of the Cocos oceanic plate under the western edge of the Caribbean plate [Molnar and Sykes, 1969]. According to seismic data the volcano stands at about $170 \mathrm{~km}$ above the local subducted slab [Carr et al.,1979].

Momotombo is a nearly perfect cone of pyroclastites and lava flows, with an open crater breached toward the northeast at its summit. Although undated, it is probably not more than a few thousands years old and has erupted once every 100 years or so since the sixtenth century [McBirney and Williams, 1965]. Its last eruption, in 1905, produced extensive lava flows of calc-alkaline basaltic andesite from the summit crater (Table 1). Since that time, intermittent fumarolic activity has persisted at Momotombo. The level of this activity increased noticeably between 1973 and 1978, the gas temperature rising from about $250^{\circ}$ to $750^{\circ} \mathrm{C}$ [Allard, 1980]. Such a change might be related to a magnitude 5.8 earthquake which occurred in March 1974 in proximity to the volcano. Intensive fumarolic degassing, with temperatures reaching $860^{\circ}-900^{\circ} \mathrm{C}$ in 1985 , has continued until now.
Table 1. Chemical Composition of Unaltered and Altered 1905 Lavas From Momotombo Volcano,Nicaragua

\begin{tabular}{|c|c|c|c|c|}
\hline & \multicolumn{2}{|c|}{ Unaltered 1905 Lava } & \multicolumn{2}{|c|}{ Altered Fumarolic Wall Rock } \\
\hline & & & Inner Part & Outer Crust \\
\hline & $\begin{array}{l}\text { Allard } \\
{[1986]^{a}}\end{array}$ & $\begin{array}{l}\text { McBimey and } \\
\text { Williams[1965] }\end{array}$ & $\begin{array}{l}\text { Allard } \\
{[1986]^{\mathrm{a}}}\end{array}$ & $\begin{array}{l}\text { Allard } \\
{[1986]^{\mathrm{a}}}\end{array}$ \\
\hline $\mathrm{SIO}_{2}$ & 53.20 & 53.00 & 56.80 & 62.24 \\
\hline $\mathrm{TiO}_{2}^{2}$ & 0.92 & 1.33 & 1.33 & 1.70 \\
\hline $\mathrm{Al}_{2} \mathrm{O}_{3}$ & 18.00 & 17.05 & 11.79 & 9.50 \\
\hline $\begin{array}{l}\mathrm{FeO} \\
\mathrm{Fe}_{2} \mathrm{O}_{3}\end{array}$ & 9.70 & $\begin{array}{l}6.24 \\
4.01\end{array}$ & 7.56 & 4.94 \\
\hline $\mathrm{MgO}^{\mathrm{J}}$ & 4.76 & 4.94 & 0.44 & 0.80 \\
\hline $\mathrm{CaO}$ & 9.55 & 9.03 & 14.93 & 16.74 \\
\hline $\mathrm{Na}_{2} \mathrm{O}$ & 2.84 & 3.14 & 1.90 & 1.17 \\
\hline $\mathrm{K}_{2} \mathrm{O}$ & 0.85 & 1.13 & 2.40 & 3.37 \\
\hline MnO & 0.18 & 0.12 & 0.15 & 0.32 \\
\hline $\mathrm{P}_{2} \mathrm{O}_{5}$ & 0.08 & 0.08 & - & - \\
\hline
\end{tabular}

The fumarolic field and the composition of the gases were described by Allard [1980, 1986], Cheminée and Delorme [1981], and Menyailov et al. [1986]. The main fumarolic zone, with the highest temperatures and gas flux, is located at the base of the southern inner wall of the crater (Figure 2). In this area the rocks are deeply altered by the hot gases and are cemented with thick sulfur encrustations. In the fumarolic vents themselves the rocks are incandescent, and red flames, up to a few tens of centimeters long, can be seen at night to escape from them. Most of the gas samples were collected in this area, deep into the vents. Another group of fumaroles, with lower temperatures $\left(550^{\circ}-100^{\circ} \mathrm{C}\right)$,

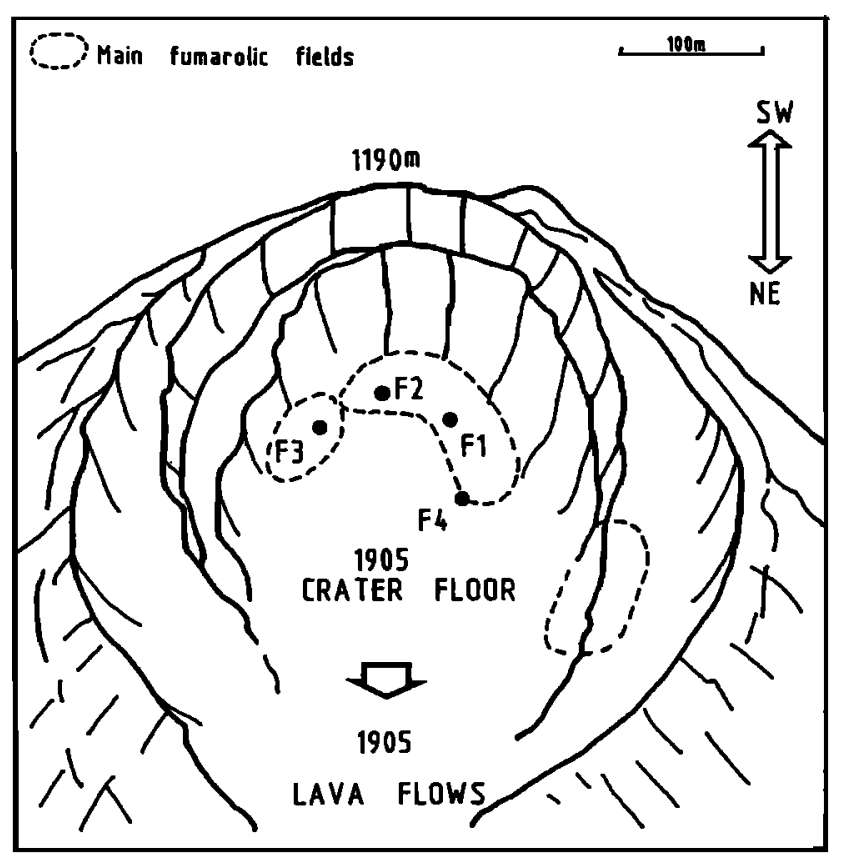

Fig.2. Schematic map of Momotombo summit crater, showing the main fumarolic fields and the most studied fumaroles (F1 to F4). 
occurs in the northern part of the crater. Weaker fumaroles also exist on the external upper slopes of the cone. Fumarolic activity in the crater of Momotombo is mainly localized on normal concentric fractures, along which the 1905 crater floor has subsided (Figure 2).

The high temperature of these surface exhalations indicates that a magma heat source occurs at a shallow depth within the volcano. In fact, the presence of a magma intrusion at a depth not exceeding a few hundreds of meters below the crater floor is strongly suggested by the results of magnetotelluric profiles carried out in 1982 on Momotombo [Sabroux et al., 1984]. The progressive increase of gas temperatures since 1973, accompanied with shallow earthquake swarms (Instituto Nicaraguense de Energia data, Managua), might signify a gradual ascent of that heat source over the past 15 years. Accordingly, the eruptive potential of Momotombo is likely to have increased in this recent period, which brought concern about the safety of a geothermal power plant newly set up at its foot (Figure 2). Such a situation provides a reliable opportunity to study the variations of both temperature and oxygen fugacity in volcanic gases before a possible eruption. In this paper we compare the $\mathrm{O}_{2}$ fugacity of the gases emitted by Momotombo during the period 1978-1985 with that of the lava erupted in 1905.

\section{Experimental Procedures}

\section{Electrochemical Measurements on Rocks and Gases}

The oxygen fugacity of Momotombo lavas was determined using the solid electrolyte technique developed for metallurgical processing and first applied to volcanological studies by Sato and Wright [1966]. The principles of measurement have been described in detail by different authors [e.g., Sato and Wright, 1966; Sato, 1972; Ulmer et al., 1976; Gantes et al., 1983].

The cell we used (Figure 3 ) consists of a CaO-stabilized zirconia tube $\left(\mathrm{ZrO}_{2}-\mathrm{CaO} 6 \mathrm{~mol} \%\right)$, coated on both sides with porous platinum, and containing a $\mathrm{Ni}-\mathrm{NiO}$ internal oxygen reference and a Pt/Pt-Rh10\% thermocouple [Amosse et al., 1982]. This cell is put into a quartz tube which is then filled with about $50 \mathrm{~g}$ of powdered rock. In order to prevent any pollution and oxidation of the sample by atmospheric oxygen, a flow of high purity deoxidized argon is made circulating into this device, allowing to obtain residual atmospheres with effective $\log f_{\mathrm{O} 2}$ of -15.0 . The great volume of the rock sample and thus the high sample/gas ratio which characterize this procedure allow to minimize the oxidizing influence of such residual atmospheres and therefore enhance the buffering ability of the rock itself.

The whole tube is introduced into an electrical furnace (Pyrox VG 30), the temperature of which is controlled by a computerized regulator (accuracy better than $1^{\circ} \mathrm{C}$ ). The samples are heated from $500^{\circ}$ to $1100^{\circ} \mathrm{C}$, with repeated heating and cooling cycles, and the emf of the solid electrolyte cell is then measured with a digital millivoltmeter (Tacussel MVN 83 with a high input impedance). Such measurements are possible only above $500^{\circ} \mathrm{C}$ owing to poor conductivity of zirconia below this temperature. The partial pressure of $\mathrm{O}_{2}$ in equilibrium with the rock sample at each temperature can then be computed from the Nernst's equation:

$$
E(\text { volt })=R T / 4 F \ln \frac{f_{\mathrm{O} 2} \text { (sample) }}{f_{\mathrm{O} 2} \text { (reference) }}
$$

where $R$ is the ideal gas constant $(8.3144 \mathrm{~J} / \mathrm{k}$. mol), $T$ the absolute temperature, and $F$ the Faraday constant $(96,485$ C). Calibrations of the oxygen fugacity sensor in air, using a standard $\mathrm{Ni}$-NiO internal reference, were previously

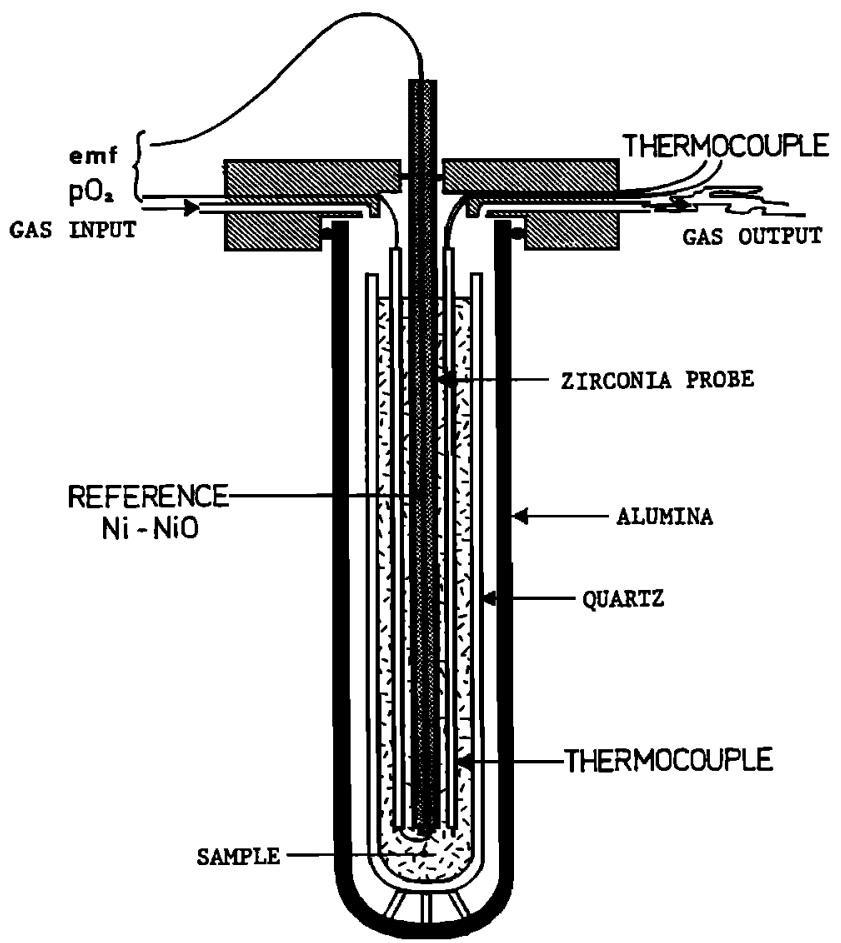

Fig.3. Description of the electrolyte cell assembly used for the intrinsic $\mathrm{f}_{\mathrm{O} 2}$ determinations on Momotombo volcanic rocks. See the text for explanation.

conducted and yielded an average uncertainty of $0.5 \%$ with respect to the theoretical curve determined by Huebner and Sato [1970]. Repeated temperature cycles performed between $500^{\circ}$ and $1100^{\circ} \mathrm{C}$ on the samples demonstrate the very good reproducibility of the measurements and the lack of any oxidation or reduction of the rocks during experiments.

Field measurements of $\mathrm{f}_{\mathrm{O} 2}$ and temperature in hot fumaroles are based on the same principle [Sato and Moore, 1973; Gantes et al., 1983]. On Momotombo, we used a small-sized (13 mm high, $1.9 \mathrm{~mm}$ wide) closed-end-tube sensor designed at the Laboratoire d'Energétique Electrochimique of Grenoble [Gantes et al., 1983]. This sensor is made of $9 \mathrm{~mol} \%$ Yttria-stabilized zirconia, with $\mathrm{Pd}-\mathrm{PdO}$ as internal $\mathrm{f}_{\mathrm{O}_{2}}$ reference, and contains a $\mathrm{Pt} / \mathrm{Pt}-\mathrm{Rh} 10 \%$ thermocouple. The inner side of the tube, which encloses the reference electrode, is rendered gas tight by means of a refractory glass seal. A platinum paint on both sides acts as the electronic conducer. The working temperature range of this sensor, determined by the Pd-PdO reference, is from $500^{\circ}$ to $900^{\circ} \mathrm{C}$, i.e., very appropriate to the study of Momotombo fumaroles.

\section{Gas Sampling and Analysis}

The analytical procedures used to sample and to analyze Momotombo gases were previously described by Allard $[1980,1986]$. Quartz tubes were used to drain the gases from the fumarole vents into preevacuated glass bottles ( 250 $\mathrm{cm}^{3}$ ) equipped with stopcocks. Some of the bottles were partly filled with either a water dessicator or a $4 \mathrm{~N}$ soda solution allowing to condense the major gas species and thereby to concentrate the "uncondensable" minor species $\left(\mathrm{H}_{2}, \mathrm{CO}, \mathrm{CH}_{4}\right.$, rare gases, etc.) in the remaining free volume. The partial pressure of these latter species could thus be determined with a very good accuracy (e.g., $\pm 5 \%$ and $2 \%$ for $\mathrm{H}_{2}$ and $\mathrm{CO}$, respectively). 
Table 2. $\mathrm{H}_{2} / \mathrm{H}_{2} \mathrm{O}$ and $\mathrm{CO} / \mathrm{CO}_{2}$ Ratios, and Calculated Equilibrium Temperature and

$\mathrm{O}_{2}$ Fugacity of Gas Samples Collected Between 1978 and 1985 at Momotombo

\begin{tabular}{|c|c|c|c|c|c|c|}
\hline Sample & Fumarole & $\begin{array}{c}\mathrm{T}^{\circ} \mathrm{C} \\
\text { Fumarole }\end{array}$ & $\begin{array}{c}\mathrm{H}_{2} / \mathrm{H}_{2} \mathrm{O} \\
\left(10^{-3}\right)\end{array}$ & $\begin{array}{c}\mathrm{CO} / \mathrm{CO}_{2} \\
\left(10^{-3}\right)\end{array}$ & $\begin{array}{c}\mathrm{T}^{\circ} \mathrm{C} \\
\text { Equilibrium }\end{array}$ & $\begin{array}{c}\log \mathbf{f}_{\mathbf{o} 2} \\
\text { Equilibrium }\end{array}$ \\
\hline \multicolumn{7}{|c|}{$02 / 1978^{\mathrm{a}}$} \\
\hline G 9 & F1 & 748 & 3.99 & 4.31 & 835 & -12.84 \\
\hline G16 & F1 & 748 & 4.59 & 5.07 & 841 & -12.85 \\
\hline G21 & F1 & 748 & 3.42 & 4.15 & 862 & -12.17 \\
\hline G22 & F1 & 748 & 4.46 & 3.35 & 739 & -15.16 \\
\hline G23 & F1 & 748 & 3.71 & 4.28 & 854 & -12.39 \\
\hline G33 & F1 & 748 & 3.75 & 4.83 & 886 & -11.56 \\
\hline G17 & F2 & 720 & 2.52 & 2.96 & 859 & -11.95 \\
\hline G19 & $F 2$ & 720 & 3.22 & 5.94 & 1008 & -9.52 \\
\hline G24 & F2 & 720 & 3.08 & 6.21 & 1042 & -8.96 \\
\hline G10 & F2 & 623 & 0.99 & 0.53 & 646 & -16.51 \\
\hline G27 & F2 & 623 & 0.87 & 0.62 & 719 & -14.28 \\
\hline \multicolumn{7}{|c|}{$\underline{08 / 1980^{a}}$} \\
\hline P17 & F1 & 802 & 5.94 & 6.07 & 820 & - 13.51 \\
\hline P48 & F1 & 802 & 4.54 & 6.03 & 897 & - 11.72 \\
\hline P08 & F2 & 780 & 4.82 & 7.33 & 849 & -12.97 \\
\hline P09 & F2 & 780 & 4.22 & 8.33 & 963 & -10.07 \\
\hline P16 & F2 & 780 & 6.46 & 7.53 & 948 & -10.86 \\
\hline P49 & F2 & 780 & 5.11 & 6.35 & 935 & -10.97 \\
\hline \multicolumn{7}{|c|}{${\underline{01 / 1981^{a}}}^{\mathrm{a}}$} \\
\hline P28 & F2 & 740 & 3.73 & 6.67 & 995 & - 9.85 \\
\hline C14 & $\mathrm{F} 2$ & 740 & 3.15 & 4.63 & 927 & -10.86 \\
\hline \multicolumn{7}{|c|}{$\underline{07 / 1981^{b}}$} \\
\hline & - & 640 & 1.72 & 1.08 & 702 & -15.28 \\
\hline \multicolumn{7}{|c|}{$\underline{03 / 1982^{c}}$} \\
\hline & F1 & 790 & 20.90 & 13.77 & 712 & -17.18 \\
\hline & F2 & 680 & 4.27 & 1.44 & 584 & -19.71 \\
\hline \multicolumn{7}{|c|}{${\underline{04 / 1983^{c}}}^{\mathrm{c}}$} \\
\hline & F1 & 858 & 12.40 & 14.90 & 866 & -13.19 \\
\hline & Fl & 819 & 8.83 & 8.73 & 811 & -14.05 \\
\hline \multicolumn{7}{|c|}{$01 / 1985^{c}$} \\
\hline & F1 & 863 & 8.69 & 14.22 & 964 & -11.09 \\
\hline & F1 & 863 & 8.94 & 15.25 & 979 & -10.87 \\
\hline
\end{tabular}

The location of fumaroles is described in Figure 2. See the text for explanation.

a This work and Allard [1986].

${ }^{b}$ Cheminée and Delorme [1981] ; average sample.

c Menyailor et al. [1986] ; average samples.

Chemical analyses were made using both gas chromatography with thermal conductivity and flame ionization detectors (gaseous phases) and electrochemistry (gases in solutions), following a routine procedure [Dajlevic et al., 1980]. Water was determined by differential weighing. The results were discussed in detail by Allard $[1980,1986]$. The $\mathrm{H}_{2} / \mathrm{H}_{2} \mathrm{O}$ and $\mathrm{CO} / \mathrm{CO}_{2}$ molar ratios of the gases, which are of major interest for the present study, are reported in Table 2 . The data concern both gas samples we collected between 1978 and 1981 and further samples gathered in 1981-1985 by Cheminée and Delorme [1981] and by Menyailov et al. [1986].

\section{Results}

\section{Rock Trend}

Whole rock. The 1905 Momotombo lava is a basaltic andesite (Table 1), with orthopyroxene, clinopyroxene, plagioclase (An50), scarce olivine and titanomagnetite as major mineral phases in a glassy matrix containing small crystals of plagioclase and titanomagnetite.

In order to assess the redox conditions which prevailed during the lava extrusion, we have determined the intrinsic oxygen fugacity of an unaltered sample of the rock between $500^{\circ}$ and $1100^{\circ} \mathrm{C}$. This lava sample was massive, about $40 \%$ crystallized, and was poorly vesiculated. The values obtained are plotted as $\log _{10} f_{22}$ against the reciprocal absolute temperature in Figure 4. One sees that they define a linear trend up to about $900^{\circ} \mathrm{C}$, the least squares fit of the data yielding the relation

$$
\log \mathrm{f}_{\mathrm{O} 2}=10.60-2.80 \times 10^{4} / \mathrm{T}^{\circ} \mathrm{K}
$$

Above $900^{\circ} \mathrm{C}$ the trend becomes clearly concave upward, even though the data set is smaller. Such a feature was previously noticed by Sato [1972] and by Sato and Moore 


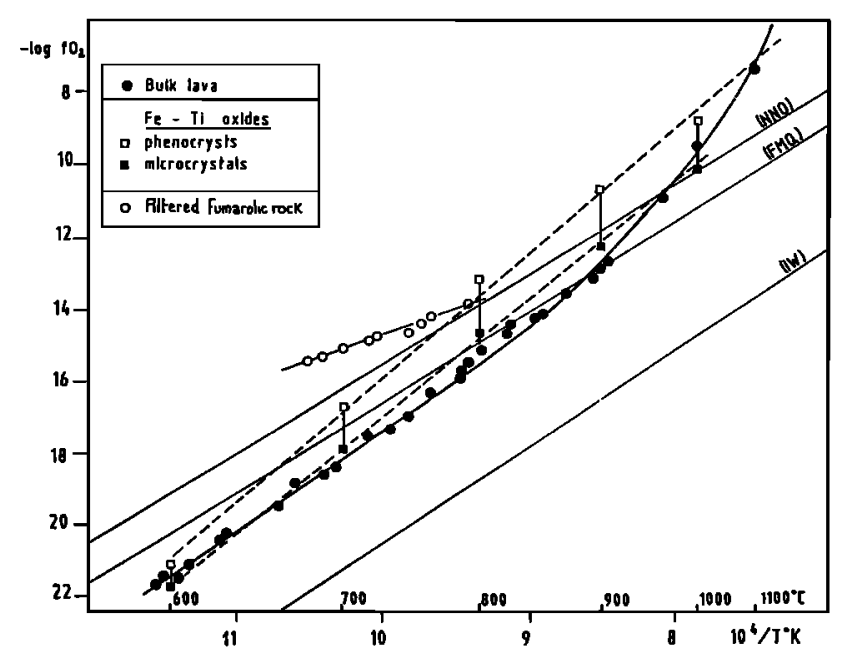

Fig.4. Oxygen fugacity-temperature relationships of Momotombo rocks: unaltered 1905 bulk lava and separate Fe-Ti oxide minerals, altered lava from the wall rock of fumaroles.The solid lines correspond to petrological oxygen buffers: nickel-nickel oxide (NNO) [Huebner and Sato, 1970], fayalite- magnetite-quartz (FMQ) [Wones and Gilbert, 1969], and, iron-wüstite (IW) [Eugster and Wones, 1962].

[1973] from similar measurements on Kilauea and Etna lavas, respectively, and is attributed to the crystallization of magnetite in that temperature range. The measured $\mathrm{O}_{2}$ fugacity thus varies from below the fayalite-magnetite-quartz (FMQ) oxygen buffer to above the nickel-nickel oxide (NNO) buffer as temperature increases, i.e., within a redox interval typical of most volcanic rocks. The $\mathrm{f}_{\mathrm{O} 2}$ of Momotombo lava, as determined by this electrochemical method, is about $10^{-7.5} \mathrm{~atm}$ at $1100^{\circ} \mathrm{C}$. For comparison, the measured $\mathrm{f}_{\mathrm{O} 2}$ of Kilauea and Etna lavas at the same temperature are $10^{-9.7}$ and $10^{-9.0} \mathrm{~atm}$, respectively [Sato, 1972; Sato and Moore, 1973]. Thus the basaltic andesite of Momotombo has a much higher oxidation state than the basalts from these two volcanoes, and we may suppose that this difference applies to the parent magmas themselves.

Mineralogical data. The $\mathrm{fO}_{\mathrm{O}}$-T relationship of volcanic rocks can also be inferred from the composition of coexisting Fe-Ti oxide minerals [Buddington and Lindsley, 1964; Spencer and Lindsley, 1981]. The Fe-Ti oxides of the Momotombo 1905 lava were therefore analyzed, using a Camebax microprobe (R.C. Maury, analyst). These are titanomagnetites with ülvospinel content ranging from $16 \%$ in phenocrysts to $42-47 \%$ in microcrystals. No ilmenite was found, thus preventing an accurate determination of a $f_{O 2}-T$ relationship from the geobarometer of Buddington and Lindsley [1964]. Nevertheless, using the Spencer and Lindsley $\mathrm{f}_{\mathrm{O} 2}-\mathrm{T}$ graph, we have tentatively inferred the $\mathrm{O}_{2}$ fugacity of these phenocrysts and microcrystals between $600^{\circ}$ and $1000^{\circ} \mathrm{C}$, the temperature interval in which data on Fe-Ti oxides are available. The calculated points are reported in Figure 4, and the lines drawn through them can be extrapolated to higher temperature. These intersect the bulk lava trend at about $1090^{\circ} \mathrm{C}$ and $\log \mathrm{f}_{\mathrm{O}_{2}}=-7.9$ for the phenocrysts and about $980^{\circ} \mathrm{C}$ and $\log \mathrm{f}_{\mathrm{O} 2}=-10.5$ for the microcrystals. Such a pattern is consistent with the expected crystallization sequence, as phenocrysts would have formed earlier, at higher temperature and thus higher $\mathrm{O}_{2}$ fugacity, than microcrystals.

Altered fumarolized rocks. The hot wall rocks making the duct of a fumarole at $700^{\circ} \mathrm{C}(\mathrm{F} 4$, Figure 2) were also sampled in order to determine their intrinsic $f_{\mathrm{O} 2}$ in laboratory. These rocks were deeply altered, as evidenced by the change in their chemistry with respect to the fresh 1905 lava (Table 1). Their $\mathrm{O}_{2}$ fugacity, measured between $650^{\circ}$ and $800^{\circ} \mathrm{C}$, plots above the (NNO) buffer and thus well above the trend for the unaltered lava (Figure 5), following a $\mathrm{f}_{\mathrm{O} 2}$-T path line described by the relation

$$
\log \mathrm{f}_{\mathrm{O} 2}=0.9-1.55 \times 10^{4} / \mathrm{T}^{\circ} \mathrm{K}
$$

Thus, the 1905 lavas which fill the crater and constitute the fumarolic ducts are much more oxidized than the unaltered lava from the same eruption. Their redox state is likely to have been modified after their emplacement by interaction with hot and oxidized volcanic fluids emitted since the 1905 eruption. Such an interpretation is supported by the results on the fumarolic gases.

\section{Gas Trend}

Electrochemical measurements. The oxygen fugacity of volcanic exhalations from Momotombo was measured in the field with the solid-electrolyte probe between 1978 and 1981. The measurements were conducted on several fumaroles with $\mathrm{T}$ ranging from $600^{\circ}$ to $800^{\circ} \mathrm{C}$. The results are plotted in Figure 5. They determine a redox field above the (NNO) buffer and fall close to or below the trend line for the altered fumarolic rocks. Since volcanic gases can only suffer oxidation during their way to the surface, the straight line which connects the more reduced values is taken to represent the best estimate of the $\mathrm{O}_{2}$ fugacity of Momotombo fumaroles for the period of investigation. This $\mathrm{f}_{\mathrm{O} 2}$ - T path is steeper than the trend line for the altered 1905 lavas and shows that the fumaroles tend to be more reduced than their host rocks, specially at lower temperature. Higher $\mathrm{f}_{\mathrm{O} 2}$ values measured on some fumaroles are attributed to near-surface air admixture or/and greater equilibration of the gas with its host ducts. The bearing of such interactions is illustrated by the results of a continuous survey of both $T$ and $\mathrm{f}_{\mathrm{O} 2}$ in fumarole $\mathrm{F} 4$, which was conducted for one week in December 1981 [Sabroux, unpublished data]. Figure 6 shows an example of the registrations obtained December $19-20,1981$, with a $10 \mathrm{mn}$ frequency data recording. While the temperature of the fumarole remained stable at around $700^{\circ} \mathrm{C}$ over the monitoring period, its $\mathrm{f}_{\mathrm{O} 2}$ displayed more

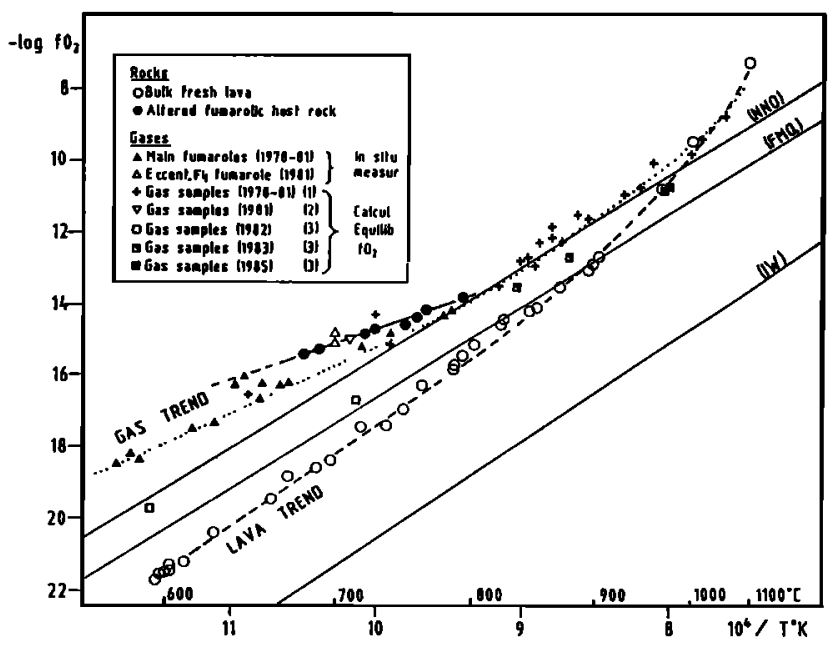

Fig.5. Comparison of the $f_{O_{2}}-T$ relationships for Momotombo gases and rocks. Bata for the gases were obtained from both field electrochemical measurements on fumaroles and thermodynamic calculations on gas samples collected between 1978 and 1985 (Table 2). See the text for discussion. 


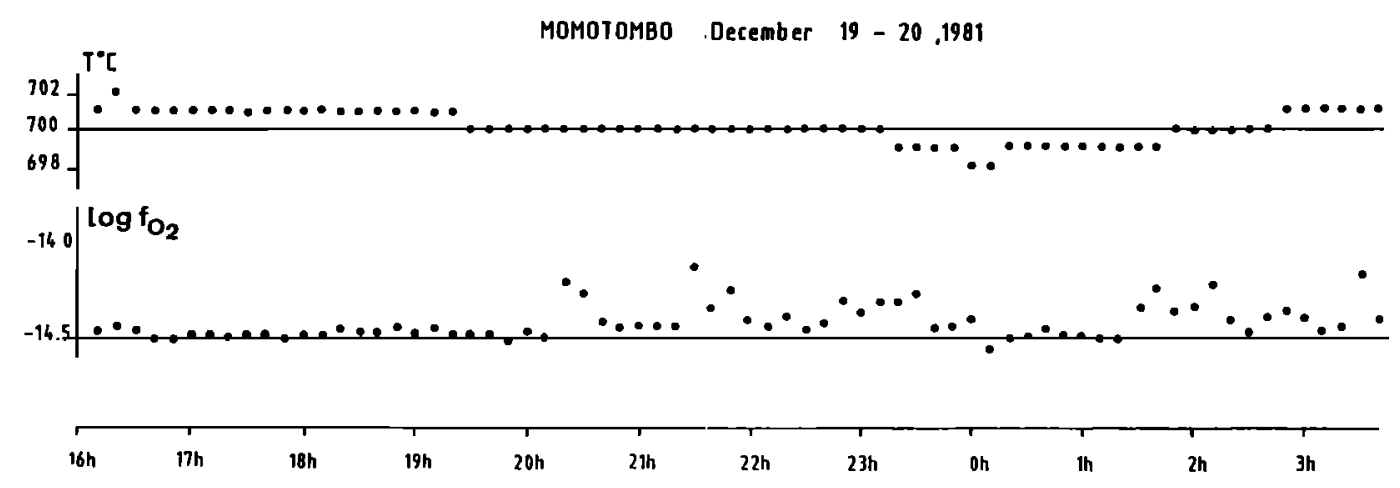

Fig.6. Continuous monitoring of $\mathrm{T}$ and $\mathrm{f}_{\mathrm{O} 2}$ at fumarole $\mathrm{F} 4$, December 19-20, 1981, with the electrochemical probe (J.C. Sabroux, unpublished data, 1981).

significant variations, including short-term peak increases which were clearly due to wind-forced air entrance into the vent. The mean $\log f_{\mathrm{O} 2}$ over one week $(-14.6 \pm 0.3$ at $700^{\circ} \mathrm{C}$ ) plots above the $\mathrm{f}_{\mathrm{O}} 2^{-\mathrm{T}}$ gas trend depicted in Figure 5 and shows a close agreement with the $f_{\mathrm{O}_{2}}$ of the corresponding altered wall rock. Thus the gas at this fumarole was particularly oxidized and tended to come into redox equilibrium with its host rocks. This may be due to the peripherical position of fumarole F4 with respect to the southern active zone (Figure 2); the lower gas flux in this area, at distance from the main conduits, would indeed allow a more extensive gas-rock equilibration, as well as a greater dilution of the rising gas by infitred air or/and vaporized groundwater. A persistent interaction of such oxidized volcanic fluids with the lavas filling the cratercan easily account for the strong alteration and oxidation of these rocks since the 1905 eruption.

These results enhance the potential reliability of electrochemical measurements, when applied to both gases and rocks, to detect temporal and spatial $f_{O 2}$ variations related to changes in volcanic activity. Indeed, any long-term isothermal decrease of this parameter at a given fumarole (e.g., fumarole F4) should be significant of an increasing contribution of more reduced fluids from depth. The electrochemical measurements carried out in 1978-1981 show that Momotombo fumaroles in this period were much more oxidized than the fresh 1905 lava at comparable temperature and were close to redox equilibrium with their altered host rocks.

Thermodynamic computations. The $\mathrm{O}_{2}$ fugacity of volcanic gas mixtures can also be inferred from their chemical composition, assuming that thermodynamic equilibrium is achieved, as previously discussed by numerous authors [Matsuo, 1960; Heald et al., 1963; Gerlach and Nordlie, 1975; Allard et al., 1977; Sabroux, 1983; Gerlach, 1983]. We have applied this approach to Momotombo gas samples collected between 1978 and 1985.

Assuming ideal gas behavior in the conditions of sampling (all fugacity coefficients equal to 1), the apparent equilibrium temperature of each gas sample was calculated from the pressure-independent water-gas shift reaction:

$$
\mathrm{CO}_{2}+\mathrm{H}_{2}=\mathrm{CO}+\mathrm{H}_{2} \mathrm{O}
$$

using the analytical proportions of these four chemical species and thermodynamic data on their free energies of formation (Barin et al., 1977). Interpolation of these latter data between $500^{\circ} \mathrm{K}$ and $1500^{\circ} \mathrm{K}$ leads to the following simplified relation:

$$
\mathbf{T}\left({ }^{\circ} \mathrm{K}\right)=\frac{1912.6}{1.7596-109 \mathrm{~K}}
$$

where $\mathrm{K}=\left(\mathrm{CO} / \mathrm{CO}_{2}\right) /\left(\mathrm{H}_{2} / \mathrm{H}_{2} \mathrm{O}\right)$ is the equilibrium constant of reaction (1). The results are reported in Table 2. Using JANAF (Joint Army, Navy and Air Force) thermodynamic data, as tabulated by Deines et al. [1974], leads to an increase in the calculated temperatures and the corresponding $f_{1}$ values of Momotombo gases (see below) of $1^{\circ}-35^{\circ} \mathrm{C}$ and $0.02-0.45 \log$ units, respectively, depending on samples.

Table 2 shows that the calculated equilibrium temperatures of Momotombo gas samples range from $650^{\circ}$ to $1040^{\circ} \mathrm{C}$, depending on fumaroles and on sampling dates, and are usually higher than the corresponding emission temperatures. In other words, the chemical proportions of the considered species (the two major components of the fluid $\left(\mathrm{H}_{2} \mathrm{O}\right.$ and $\left.\mathrm{CO}_{2}\right)$ and their two reduced counterparts $\left(\mathrm{H}_{2}\right.$ and $\mathrm{CO}$ ) were not equilibrated in the surface conditions of their emission but rather preserved the (variable) memory of a higher thermal equilibrium achieved at depth. In fact, the equilibrium $\mathrm{f}_{\mathrm{O} 2}$ of the gas samples at their respective collection temperature, as calculated from their $\mathrm{CO} / \mathrm{CO}_{2}$ ratio (see below), had been found to be lower than the $\mathrm{f}_{\mathrm{O}_{2}}$ directly measured in the fumaroles, thereby indicating that $\mathrm{CO}$ was in excess in the gas with respect to the redox conditions defined by the field electrochemical measurements (Allard, 1986). Such an observation, which frequently applies to volcanic gas mixtures, therefore indicates that the kinetics of chemical reequilibration between those species along with cooling was slower than the velocity of the gas transfer to the surface.

The equilibrium $\mathrm{O}_{2}$ fugacities at the above calculated temperatures can then be obtained from either of the following two redox equilibria:

$$
\begin{aligned}
& \mathrm{H}_{2}+1 / 2 \mathrm{O}_{2}=\mathrm{H}_{2} \mathrm{O} \\
& \mathrm{CO}+1 / 2 \mathrm{O}_{2}=\mathrm{CO}_{2}
\end{aligned}
$$

with $\left.\log \mathrm{f}_{\mathrm{O} 2} \mathrm{~T}\right)=2\left(\log \mathrm{K}_{3}-\log \mathrm{H}_{2} / \mathrm{H}_{2} \mathrm{O}\right)=2\left(\log \mathrm{K}_{4}-\log \right.$ $\left.\mathrm{CO} / \mathrm{CO}_{2}\right), \mathrm{K}_{3}$ and $\mathrm{K}_{4}$ being the respective equilibrium constants of reactions (3) and (4). The values are listed in Table 2 and are reported in Figure 5. The $\mathrm{f}_{\mathrm{O} 2}$ obtained for those 1978-1981 samples with equilibrium temperatures between $600^{\circ}$ and $800^{\circ} \mathrm{C}$ (including the average sample of Cheminée and Delorme [1981]) closely fit with the trend defined by field electrochemical measurements performed in the same period. The samples with equilibrium temperatures above $800^{\circ} \mathrm{C}$ allow to extend this trend toward higher temperatures. It can be pointed out that the so-defined "gas trend" tends to parallel the (NNO) buffer but becomes concave upward above $850^{\circ} \mathrm{C}$ and then crosses over the 1905 lava trend at about $1050^{\circ} \mathrm{C}$ and $\log \mathrm{f}_{\mathrm{O}}=-9.0$. Hence the gases collected from Momotombo in 1978-1981 were generally much more oxidized than the 1905 lava, the 


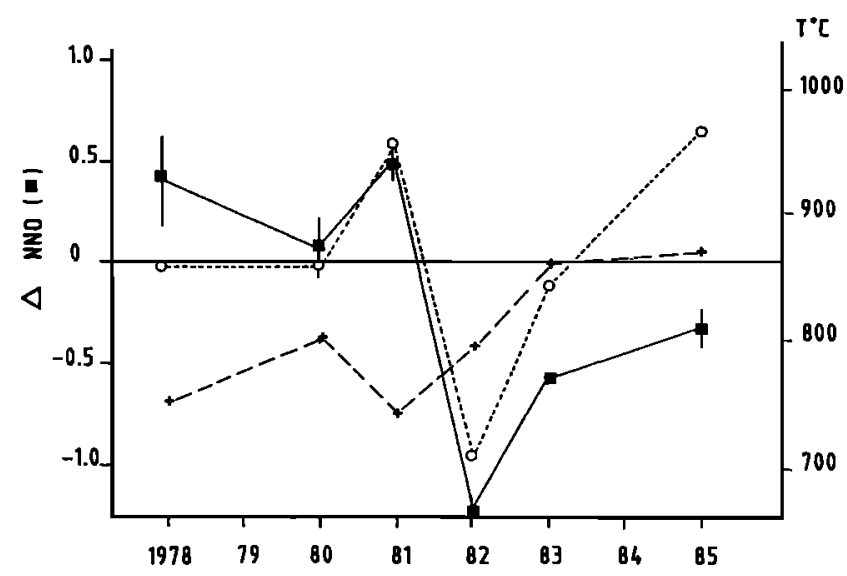

Fig.7. Temporal evolution of both equilibrium $\mathrm{f}_{\mathrm{O}_{2}}$ and temperature of gas samples collected at fumarole $\mathrm{F} 1$ between 1978 and 1985 . The average equilibrium $\mathrm{f}_{2}$ values for successive sampling are reported as deviations with respect to the (NNO) buffer, defined as $\Delta \mathrm{NNO}=\log \mathrm{f}_{\mathrm{O}_{2}}$ (sample) $\log f_{2}$ (NNO). Solid circles represent the correspon- ding equilibrium temperatures; crosses describe the measured emission temperature at the same dates. While this latter increased from $750^{\circ} \mathrm{C}$ to $860^{\circ}-900^{\circ} \mathrm{C}$ between 1978 and 1985 , the $\triangle N N O-T_{\text {equil }}$ relationship of gas samples indicates a simultaneous evolution toward more reduced conditions.

difference increasing as temperature decreases; however, some of them preserved a redox signature which is very similar to that of the lava under eruptive temperature conditions. This strongly suggests that at least some of these gases would have experienced equilibrium with a molten silicate at depth, this latter being shallow enough for limiting their subsequent cooling and oxidation during ascent. Gas samples from other fumaroles, with lower equilibrium temperature and $\mathrm{f}_{\mathrm{O} 2}$, might also have equilibrated with that melt but clearly suffered greater cooling and late oxidation, from either more extensive reactions with the wall rocks, dilution by superficial fluids, or even preferential $\mathrm{H}_{2}$ loss through the central gas channels.

The Momotombo gases further collected between 1982 and 1985 by Menyailov et al. [1986] have a lower equilibrium $\mathrm{f}_{\mathrm{O}}$ than the 1978-1981 ones (Figure 5). They plot below the (NNO) buffer and therefore closer to the lava trend, with $\mathrm{f}_{2} 2$ values about one log unit lower than those for the 1978-1981 samples at comparable equilibrium temperature. Altogether, they would determine a new, more reduced $\mathrm{f}_{\mathrm{O} 2}-\mathrm{T}$ gas trend, with a steeper slope than the 1978-1981 one. Since the experimental methods used by the Menyailov's group and ourselves were rather similar, such a change can be considered significant. It is illustrated in Figure 7 , where the average $f_{O 2}$ values for successive sampling at the hottest fumarole $(F 1)$ have been normalized to the (NNO) buffer, as

$$
\Delta \mathrm{NNO}=\log \mathrm{f}_{\mathrm{O} 2} \text { (sample) }-\log \mathrm{f}_{\mathrm{O} 2} \text { (NNO) }
$$

When comparing samples with close equilibrium temperatures (e.g., the 1978, 1980 and 1983 samples, or the 1980 and 1985 ones), then it becomes apparent that their $\Delta N N O-T_{\text {equil. }}$ relationship has evolved toward more reduced conditions (negative $\triangle$ NNO values) along with time. Such a change happened together with an overall increase of the emission temperature of the fumarole (Figure 7) and with an increase of both the $\mathrm{H}_{2} / \mathrm{H}_{2} \mathrm{O}$ and $\mathrm{CO} / \mathrm{CO}_{2}$ ratios of the gas (Table 2). Therefore volcanic exhalations from Momotombo are likely to have gained a more reduced character over this recent time interval which, according to the model presented above, would imply that their link with the magma degassing at depth has become still closer.

\section{Conclusions}

The redox state of gases and rocks from Momotombo volcano has been studied by several methods. Field electrochemical measurements show that the high-temperature fumaroles of the volcano are much more oxidized, at equivalent temperature, than the unaltered lava from the last 1905 eruption and tend to be in redox equilibrium with their altered host rocks. Thermodynamic computations on gas samples however suggest that the rising gases may initially equilibrate with a magma body at shallow depth under $\mathrm{T}$ and $\mathrm{f}_{\mathrm{O} 2}$ conditions of at least $1050^{\circ} \mathrm{C}$ and $10^{-9.0} \mathrm{~atm}$, respectively. Unbuffered cooling after their separation from the melt, together with near-surface interactions with environmental fluids and rocks, would account for their subsequent oxidation during ascent. This oxidation remains minimal when the fumarolic vents are both air tight and closely connected with the central gas conduits. It is greater at peripherical vents, where the gas flux is weaker and where late equilibration with the host rocks and dilution by entrained air or/and groundwater can be larger. Highly oxidized volcanic fluids emitted since the last eruption in 1905 have thus extensively altered the chemistry and the redox state of the lava which plugs the crater and makes the wall rock of the fumaroles.

These results suggest that continuous monitoring of both the temperature and $\mathrm{O}_{2}$ fugacity of selected Momotombo fumaroles, using electrochemical sensors, should provide valuable information on changes in the conditions of magma degassing at depth. Indeed, any increase of the deep gas flux or/and rising of the magma before an eruption would make the fumarolic gases progressively less affected by cooling and late oxidation, and therefore progressively more reduced with respect to their host rocks. Their measured (intrinsic) $\mathrm{f}_{\mathrm{P} 2}$ should then decrease at a given temperature or, rather, should rise along a more reduced $\mathrm{f}_{\mathrm{O} 2}-\mathrm{T}$ gas trend line. The overall lowering of the equilibrium $\mathrm{f}_{\mathrm{O} 2}$ of Momotombo gas samples collected at fumarole $F 1$ between 1978 and 1985 is considered representative of such an evolution, the more so as it occurred together with an increase of the fumarole temperature. Unfortunately, no electrochemical measurements were performed after 1981 , thus preventing us to confirm a simultaneous decrease of the $\mathrm{f}_{\mathrm{O} 2}$ at emission.

Conditions for eruption in the future could be presumably achieved when the intrinsic $\mathrm{f}_{\mathrm{O}}$ of the fumaroles will reach the 1905 lava trend, i.e., when the fumarolic gas at emission will become as reduced as the lava itself. Because the rock layers presently filling Momotombo crater are highly oxidized and therefore would tend to increase the $\mathrm{O}_{2}$ fugacity of any gas rising through them, this could only occur when new lava will arrive close to or extrude at the surface. In the present noneruptive stage the crossing point between the $f_{O} 2-T$ gas and lava trends is obtainable only from thermodynamic treatment of collected gas samples, the chemical proportions of gas species being less sensitive to late air admixture or/and to temperature, and thus $\mathrm{f}_{\mathrm{p}} 2$ reequilibration, than the whole fumarolic exhalation. This illustrates the complementary usefulness of both continuous and discontinuous measurements on volcanic gases for monitoring purposes.

The question remains as to whether the intrinsic $\mathrm{f}_{\mathrm{O}_{2}}$ of the 1905 lava is representative of that of future eruptive products from Momotombo. Volatile loss during extrusion and cooling of this lava in 1905 might have modified its 
original redox state, oxidation being favored by the escape of $\mathrm{H}_{2}$ [Sato and Wright, 1966; Sato, 1978] and the degassing of $\mathrm{CO}_{2}$ [Mathez, 1984], reduction being favored by the release of $\mathrm{SO}_{2}$ [Sakai et al., 1982]. The net effect would thus have depended on the initial amount and proportions of $\mathrm{H}, \mathrm{C}$ and $\mathrm{S}$ species in the melt, as well as on their degassing mode. Lacking the data to settle this point, let us assume that the $\mathrm{f}_{\mathrm{O} 2}$ of the 1905 Momotombo lava well approximates the $\mathrm{f}_{2}$ of its parent magma before extrusion. If we further admit that the magma body presently underlying the volcano has a similar redox state as the 1905 melt, which is a reasonable assumption, then its reducing influence on the fumaroles prior to a future eruption should be well detectable. Continuous electrochemical monitoring of Momotombo exhalations should allow to verify the foundation of this model.

Acknowledgments. This work was supported by the Centre National de la Recherche Scientifique (CNRS) (Programme Interdisciplinaire pour la Recherche et la Surveillance des Eruptions Volcaniques), by the French Ministry for Foreign Affairs and by the Instituto Nicaraguense de Energia (INE) of Nicaragua. Thanks are due to P. Ochin and C.Petot (Villetaneuse University) for their contribution to the $f_{\mathrm{O} 2}$ measurements on rock samples, and to R.C. Maury (Brest University) and C. Jehanno (Centre des Faibles Radioactivités) for the petrographic analyses of Momotombo rocks and minerals. A.Rodriguez Alvarado (Ministerio de Planificacion, Nicaragua) and people from the French embassy in Managua provided an invaluable assistance to this study. G.C. Ulmer and $\mathbf{M}$. Sato's comments greatly improved the first version of this paper. This is Centre des Faibles Radioactivités contribution n'923.

\section{References}

Allard, P., Composition isotopique du carbone dans les gaz d'un volcan d'arc: Le Momotombo (Nicaragua),C.R. Acad. Sci., 290, 1525-1528, 1980.

Allard, P., Géochimie isotopique et origine de l'eau du carbone et du soufre dans les gaz volcaniques: zones de rift, marges continentales et arcs insulaires, thèse d'état, $352 \mathrm{pp}$., Univ. Paris VII, 1986.

Allard, P., F. Le Guern, and J.C. Sabroux, Thermodynamic and isotopic studies in eruptive gases, Geothermics, 5, 37-40, 1977.

Amosse, J., J. Fouletier, and M. Kleitz, Application of solid electrolyte cells to the field of geoscience, Bull, Minéral. 105, 188-192, 1982.

Anderson, A.T., Some basaltic and andesitic gases, Rev. Geophys., 13, 37-55, 1975.

Barin, I., $O$. Knake, and $O$. Kubachewski, Thermodvnamical Properties of Inorganic Substances, 487 pp., Springer-Verlag, New York, 1977.

Buddington, A.F., and D.H. Lindsley, Iron-titanium oxide minerals and synthetic equivalents, J. Petrol., 54, 310-357, 1964.

Carapezza, M., P.M. Nuccio, and M. Valenza, Geochemical surveillance of the Solfatara of Pozzuoli, Phlegrean Fields, during 1983, Bull. Volcanol, 47, 303-311, 1984.

Carr, M.J., W.I. Rose, and D.G. Mayfield, Potassium content of lavas and depth to the seismic zone in Central Amarica, J. Volcanol. Geotherm. Res., 5, 387-401, 1979.

Cheminée, J.L., and H. Delorme, Gas analyses at three Central American volcanoes, SEAN Bull. 6,7, 2, July 1981 .
Dajlevic, D., P. Zettwoog, P. Allard and J.C. Sabroux, Méthodes de prélèvement et d'analyse des gaz volcaniques: exemple de l'éruption d'Ardoukoba, 7-14 Nov. 1978, CEA Rep, N-2128, 26 pp., Commis. a l'Energie At., Gif sur Yvette, France, 1980.

Deines, P., R.H. Nafziger, G.C. Ulmer, and E. Woermann, Temperature-oxygen fugacity tables for selecyed gas mixtures in the system $\mathrm{C}-\mathrm{H}-\mathrm{O}$ at one atmosphere total pressure, Bull. Earth Miner. Sci. Exp. Stn. P. State Univ. 88, 129 pp., 1974.

Eugster, H.P., and D.R. Wones, Stability relations of the ferruginous biotite, annite, J. Petrol., $\underline{3}$, 82-125, 1962.

Fudali, R.F., Oxygen fugacity of basaltic and andesitic magmas, Geochim. Cosmochim. Acta, 29, 1063-1075, 1965.

Gantes, M., J.C. Sabroux, and G. Vitter, Chemical sensors for monitoring volcanic activity, in Forecasting Volcanic Events, edited by $\mathrm{H}$. Tazieff and J.C. Sabroux, pp. 409-424, Elsevier, Amsterdam, 1983.

Gerlach, T.M., Intrinsic chemical variations in high-temperature gases from basic lavas, in Forecasting Volcanic Events, edited by $H$. Tazieff and J.C. Sabroux, pp. 323-336. Elsevier, Amsterdam,1983.

Gerlach, T.M., and B.E. Nordlie, Temperature, atomic composition and molecular equilibria in volcanic gases, art II, Am. J. Sci., 275, 377-394, 1975.

Haggerty, S.E., The redox state of planetary basalts, Geophys. Res. Lett., 5, 443-446, 1978.

Heald, E.F., J.J. Naughton, and I.L. Barnes, The chemistry of volcanic gases, 2, Use of equilibrium calculations in the interpretation of volcanic gas samples, J. Geophys. Res, 68, 545-557, 1963.

Huebner, J.S., and M. Sato, The oxygen fugacity-temperature relationships of manganese oxide and nickel oxide buffers, Am. Mineral, 55, 934-952, 1970.

Mathez, E.A., Influence of degassing on oxidation states of basaltic magmas, Nature, 310 , 371-375, 1984.

Matsuo, S., On the origin of volcanic gases, $\mathrm{J}$. Earth Sci. Nagoya Univ. 8 , 222-24 1960.

McBirney, A.R., and H. Williams, Volcanic history of Nicaragua, Univ, Calif. Berkeley Publ. Geol. Sci, 55, 1-65, 1965 .

Menyailov, I.A., L.P. Nikitina, V.N. Shapar, and V.P. Pilipenko, Temperature increase and chemical change of fumarolic gases at Momotombo volcano, Nicaragua, in 1982-1985: Are these indicators of a possible eruption? $\mathrm{L}$ Geophys. Res. 91, 12,199-12,214, 1986.

Molnar, P., and L.R. Sykes, Tectonics of the Caribbean and Middle and seismicity, Geol. Soc. Am. Bull., 80, 1639-1684, 1969.

Sabroux, J.C., P. Allard, A. Creusot, D. Dajlevic, M. Gantes, and M. Halbwachs, Surveillance géochimique et géophysique du volcan Momotombo, Nicaragua, paper presented at Colloque PIRPSEV-CNRS, Programme Interdisciplinaire de Rech. sur la Prévision et de la Surveillance des Eruptions Volcaniques/Cent. Natl. de la Rech. Sci., Clermont-Ferrand, France, 1984. 
Sakai, H., T. Casadevall, and J.G. Moore, Chemistry and isotope ratios of sulfur in basalts and volcanic gases at Kilauea volcano, Hawaii, Geochim. Cosmochim. Acta. 46, 729-738, 1982.

Sato, M., Intrinsic oxygen fugacities of iron-bearing oxide and silicate minerals under low total pressure, Mem.Geol. Soc. Am., 135, 289-307, 1972.

Sato, M., Oxygen fugacity of basaltic magmas and the role of gas-forming elements, Geophys. Res. Lett., 5, 447-449, 1978.

Sato, M. and K. McGee, Continuous monitoring of hydrogen on the South flank of Mt. Saint Helens, U.S.Geol.Surv. Prof. Pap., 1250, 209-220, 1981.

Sato, M., and J.G. Moore, Oxygen and sulphur fugacities of magmatic gases directly measured in active vents of Mount Etna, Philos. Trans. R. Soc. London Ser., A. 274, 137-146, 1973.

Sato, M., and T.L. Wright, Oxygen fugacities directly measured in magmatic gases, Science, 153, 1103-1105, 1966.

Sato, M., S.D. Malone, R.M. Moxham, and J.E. Mc Lane, Monitoring of fumarolic gas at Sherman Crater, Mount Baker, Washington abstract, Eos Trans.AGU, 57, 88-89, 1976.

Spencer, K.J., and D.H. Lindsley, A solution model for coexisting iron-titanium oxides, Am. Mineral., 66, 1189-1201, 1981.
Tazieff, H., and J.C. Sabroux, (Eds.), Forecasting Volcanic Events, 551 pp., Elsevier, Amsterdam, 1983.

Ulmer, G.C., M. Rosenhauer, E. Woermann, J. Ginder, A. Drory-Wolf, and P. Wasilewski, Applicability of electrochemical oxygen fugacity measurements to geothermometry, A m. Mineral., 61, 653-665, 1976.

Wones, D.R., and M.C. Gilbert, The fayalite-magnetite-quartz assemblage between $600^{\circ} \mathrm{C}$ and $900^{\circ} \mathrm{C}$, Am. J. Sci., 267 A, 480-488, 1969.

P. Allard, G. Benhamou, and J.C. Sabroux, Centre des Faibles Radioactivités, Laboratoire mixte CNRS-CEA, Domaine du CNRS, Avenue de la Terrasse, 91190 Gif sur Yvette, France.

A. Creusot, Instituto Nicaraguense de Energia, Apartado 55, Managua, Nicaragua.

D. Dajlevic, CEA, SPIN-DPT, CEN Saclay, B.P. 2, 91190 Gif sur Yvette, France.

G. Vitter, Laboratoire d'Energétique Electrochimique, ENSEEG, Domaine Universitaire, B.P. 44, 38041 Saint Martin d'Hères, France.

(Received December 15, 1986 ; revised March 28, 1988 ; accepted May 2, 1988.) 